\title{
Obesity and immune function relationships
}

\author{
A. Martí ${ }^{1}$, A. Marcos ${ }^{2}$ and J. A. Martínez ${ }^{1}$
}

'Department of Physiology and Nutrition, University of Navarra, C//runlarrea s/n 31080 Pamplona (Navarra), Spain; ${ }^{2}$ Institute of Nutrition and Food Science, Complutense University of Madrid, Faculty of Pharmacy 28040 Madrid, Spain

Received 24 July 2000; revised 19 October 2000; accepted 25 October 2000

Address reprint requests to: Prof. J. Alfredo Martínez, 'Department of Physiology and Nutrition, University of Navarra, C/lrunlarrea s/n 31080 Pamplona (Navarra), Spain

E-mail: jalfmtz@unav.es

\begin{abstract}
Summary
The immunological processes involved in the collaborative defence of organisms are affected by nutritional status. Thus, a positive chronic imbalance between energy intake and expenditure leads to situations of obesity, which may influence unspecific and specific immune responses mediated by humoral and cell mediated mechanisms. Furthermore, several lines of evidence have supported a link between adipose tissue and immunocompetent cells. This interaction is illustrated in obesity, where excess adiposity and impaired immune function have been described in both humans and genetically obese rodents. However, limited and often controversial information exist comparing immunity in obese and non-obese subjects as well as about the cellular and molecular mechanisms implicated. In general terms, clinical and epidemiological data support the evidence that the incidence and severity of specific types of infectious illnesses are higher in obese persons as compared to lean individuals together with the occurrence of poor antibody responses to antigens in overweight subjects. Leptin might play a key role in linking nutritional status with T-cell function. The complexities and heterogeneity of the host defences concerning the immune response in different nutritional circumstances affecting the energy balance require an integral study of the immunocompetent cells, their subsets and products as well as specific and unspecific inducer/regulator systems. In this context, more research is needed to clarify the clinical implications of the alterations induced by obesity on the immune function.
\end{abstract}

Keywords: Adipose tissue, Fat deposition, Immunity, Nutrition.

obesity reviews (2001) 2, 131-140

\section{Introduction}

The immune system protects the individual through different cellular and molecular mechanisms, which are designed to identify its own cells and substances, but also to detect and destroy/block foreign organisms and their products $(1,2)$.

There are two principal branches of the immune response (2), which are categorized as innate (unspecific) or acquired (specific). Innate or natural immunity does not require previous exposure and includes the following components: physical barriers and mucous membranes; the complement system, antimicrobial substances such as lisozyme and other inflammation mediators as well as phagocytes (neutrophyls and macrophages) and other leucocytes such as natural killer (NK) cells, which are able to lysate virus and tumour-bearing cells. On the other hand, acquired or adaptive immunity comes into play because of previous contact and memory, which is usually assigned to two broad categories: (i) humoral immunity, in which Blymphocytes synthesize and release specific antibodies consisting of five different immunoglobulin subtypes and (ii) cell-mediated immunity that depends on various thymusprocessed lymphocyte subsets (T-lymphocytes) and their products: the lymphokines, which are efficient against a number of antigens. Sub-populations of T-lymphocytes can be functionally ascribed as helper $\mathrm{T}$ lymphocytes $(\mathrm{Th})$ or cytotoxic/suppressor T-lymphocytes $(\mathrm{Tc})$ depending of the cluster of differentiation expression $(\mathrm{CD} 4+$ and $\mathrm{CD} 8+$, respectively).

In this context, T-lymphocytes specifically destroy those cells releasing antigens because they are infected by virus 
or other intracellular micro-organisms, while humoral immunity is the major defence mechanism against extracellular micro-organisms and their toxins (3).

The two tiers of the immunocompetence system are not isolated, but they function within a co-ordinated model in order to develop an integrated defence against undesirable infections, cell damage or pathogenetic mechanisms (3). Good examples of this interaction are the stimulation of $\mathrm{T}$ helper lymphocytes by an antigen to produce lymphokines, which promote the proliferation and differentiation of macrophages as well as the interplay between Th and B lymphocytes (CD19+), which lead to immunoglobulin production by inducing $\mathrm{B}$ cells to change to antibodyproducing plasma cells. Furthermore, antigen presenting cells (e.g. macrophages) facilitate the introduction of antigen to both $\mathrm{T}$ and B-cells, while delayed cutaneous hypersensitivity response both to recall or new antigens arisen by the skin is another response mediated by lymphocytes. A practical corollary of the integral defence of the living organism is the collaborative involvement of different immunological mechanisms in order to protect the individual (Fig. 1).

\section{Nutrition, immunity and disease}

The mutual interactions among nutrition, immune function and the pathological condition (Fig. 2) are multifactorial $(4,5)$. Thus, nutrient intake and nutritional status influence host immunocompetence and the body's response to illness or infection; immune impairments bring about detrimental effects on nutrient utilization and affect the outcome to disease and infections challenges, and some pathogenic micro-organisms or sicknesses may induce malnutrition and immunodeficiency. Hence, anthropometric and biochemical determinations have been correlated with dietary intake and clinical examinations, but also with immunological measurements $(6,7)$.

In this context, clinical and epidemiological evidences have demonstrated that immunocompetence depends upon the nutritional status, since malnutrition is involved in impaired immune responses and an increased prevalence of infection (8). Excessive intake of certain nutrients may enhance the immunocompetence, but also may induce some immunodeficiencies $(4,9)$. Also, the qualitative and quantitative nutrient composition of the dietary intake have been involved in the regulation of the immune response $(10,11)$. Lymphoid tissues, with a rapid turnover appear to be extremely vulnerable to nutrient imbalances affecting metabolic pathways and functions implicated in the immune defence. Furthermore, infections are associated to a decreased food intake, intestinal catabolic stress and increased losses of nutrients through faeces, urine and sweat, which are accompanied by impaired protein synthesis (immunoglobulins) and cell proliferation demands (12).

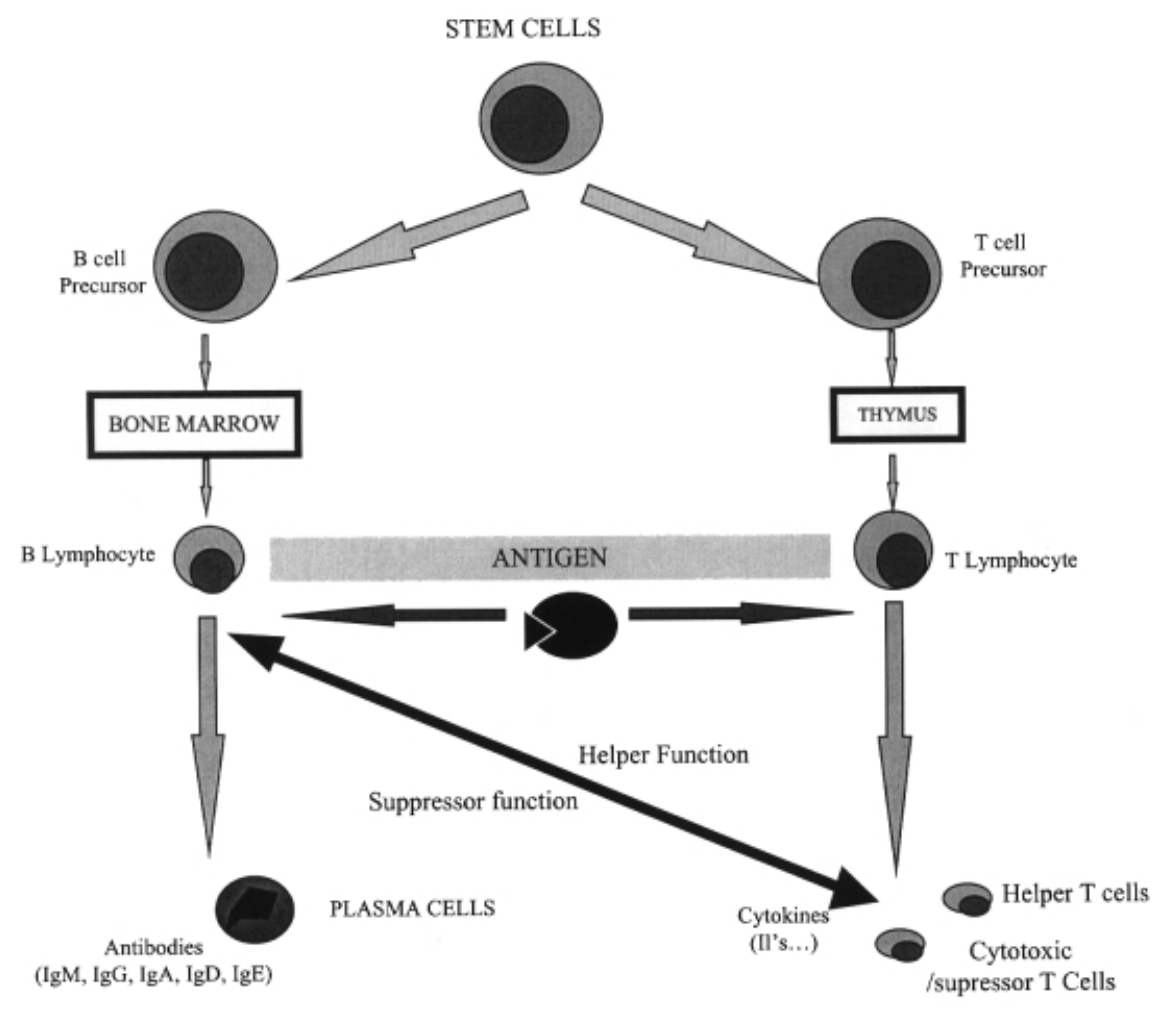

Figure 1 Development and interactions between humoral and cell-mediated immunity. 
Figure 2 Interaction between nutritional status, host immunodefence and disease.

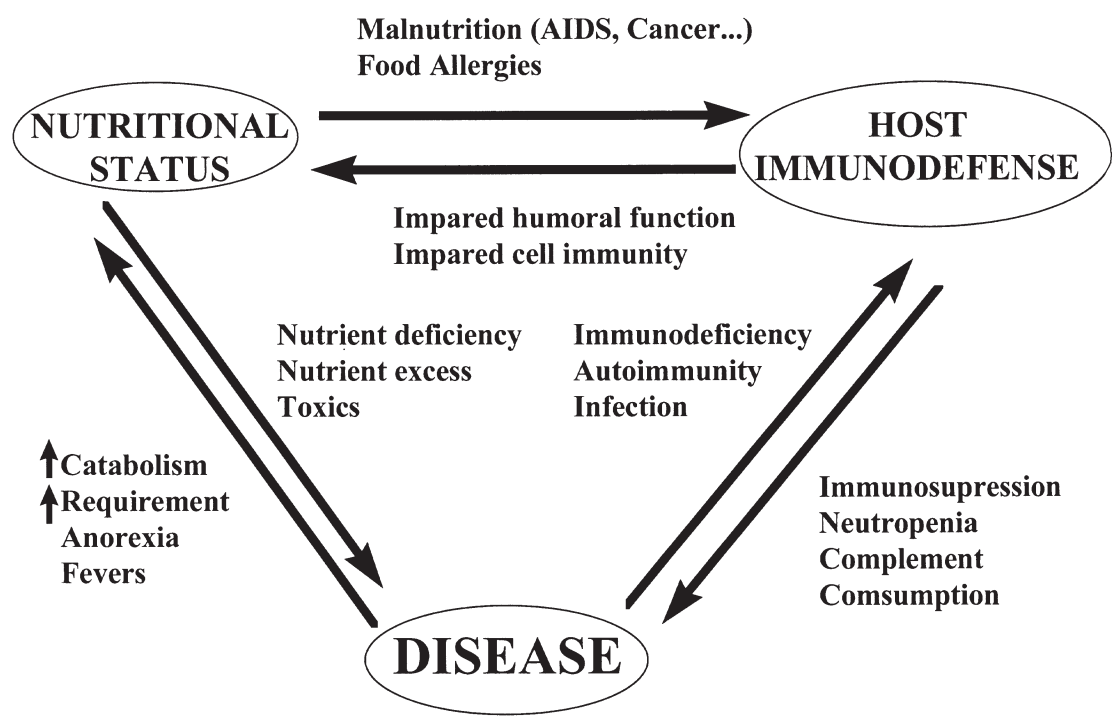

The assessment of the nutritional status may be accomplished through a number of immunological measurements such as leucocytes and lymphocytes sub-populations counts, lymphoblastic proliferation stimulated by different antigens, leucocyte migration and phagocyte function, delayed hypersensitivity reactions, plasma concentration of different immunoglobulins (antibodies) and production or activity of complement components, cytokine and other mediators including interferon $(\alpha, \beta, \gamma) \ldots$, interleukins, B-cell differention factors, monokines, etc. (3). In any case, cutaneous assays as well as lymphocyte counting and functional determinations are the most commonly applied tests in nutritional evaluation (13).

\section{Energy balance, adipose tissue and immunity interactions}

Energy balance and body composition depend upon energy intake and expenditure $(14,15)$, which appears to be under control on an axis with three components; (i) food intake; (ii) fuel utilization and thermogenesis and (iii) adipocyte metabolism. In this context, obesity is a pathological condition accompanied by an excessive fat deposition as compared to the expected values for a given stature, sex and age, which is often estimated by a body mass index $\left(\mathrm{kg} / \mathrm{m}^{2}\right)$ higher than $30(16,17)$. This alteration of energy homeostasis has been attributed to a number of causes such as neuroendocrine factors, metabolic disturbances and genetic traits as well as to psychological influences or changes in lifestyle such as excessive energy intake or reduced physical activity $(18,19)$. Occasionally, the hypothesis linking obesity with an infectious agent has attracted some attention (20).

Obesity has been related to hypertension, hypercholesterolaemia, certain tumours and cardiovascular diseases
(21), but also to immune dysfunction $(22,23)$, which are accompanied by a higher rate of infections and increased risk of delayed wound healing $(24,25)$. Also, some reports have linked to a lower production of antibodies after hepatitis B vaccination in obese patients (26), while other studies conducted in animals showed that obesity produced impairments in the immune response $(27,28)$. Furthermore, results from Gottschlich and co-workers (29) revealed that the incidence and severity of infectious diseases were higher in burn obese patients, than in burn lean men. Thus, bacteriaemia and clinical sepsis occurred more concomitant with obesity (9 out 15 patients) as compared with nonobese controls ( 2 out 15 ), while the antibiotic therapy was required for more than twice as many days in the obese group than in the control group, although this trend did not reach statistical significance (Fig. 3). Compared with normal-weight burn subjects, obese-burn patients had markedly lower $\alpha-2$ macroglobulin levels through the study period. On the other hand, certain studies have focused on the immune response in some situations, in which the adipose tissue is depleted such as bulimia (30) anorexia nervosa (31), and ADIS (32) patients and the results are controversial. Thus, some reports have shown functional cellular abnormalities, while others have found normal above T-lymphocyte populations and proliferative responsiveness to mitogenic stimulation.

Adipose tissue is not only an energy store, but it is involved in a number of functions as an endocrine organ (33). Thus, immune-related proteins produced by adipocytes include adipsin, acylation stimulation protein, adipocyte complement related protein, tumour necrosis factor $\alpha$ (TNF- $\alpha)$, leptin, etc. Also, leucocytes are believed to contribute to the adipose tissue metabolism for their ability to influence fat deposition. Furthermore, some 


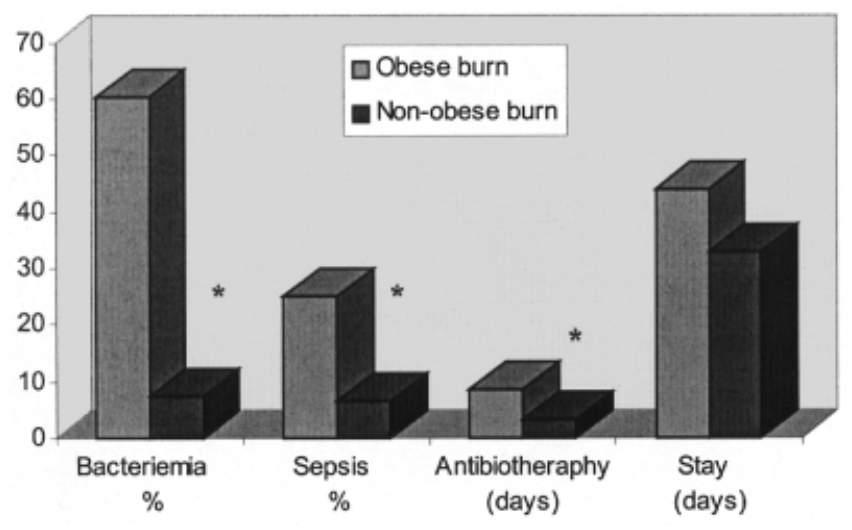

Figure 3 Clinical outcome related to incidence of infection in obese and non-obese individuals (Adapted from Gottschlich et al. 1993(29)) ${ }^{\star} P<0.05$

results suggest that preadipocytes could function as macrophage-like cells and raise the possibility of a potential direct participation of adipose tissue in inflammatory processes (34). Also, the macrophage migration inhibitory factor (MIF), the first T-cell-derived soluble lymphokine to be identified, is expressed in adipocytes, which suggests its involvement in various biological events such as wound healing, atopic dermatitis, and possibly, diabetes/obesity (35).The recent description of the mahogany mouse mutation provided further links between obesity and the immune system (36). The peroxisome proliferator activated receptor $(\operatorname{PPAR} \gamma)$, which is highly expressed in adipose tissue, appears to be a key modulator of adipogenesis, but also appears to be involved in macrophage function (37).

Further evidence of fat metabolism and immunity interactions comes from the fact that the fatty acid composition of phospholipids from splenocyte membranes are affected by dietary lipid manipulation, and these differences influenced lymphocyte functions $(4,11)$. Thus, increased levels of linoleic acid in spleen lymphocytes correlated negatively with interleukin- 2 receptor $\alpha$-chain expression and with the cell proliferation index. Furthermore, immunosuppressive effects induced by polyunsaturated fatty acids could be due to an increase of linoleic acid or a decrease of oleic acid modifying many components of plasma membraneassociated events involved in lymphocyte activation (11). Interestingly, immune function and energy balance have been related in functionally beneficial ways to fat content and distribution (38), which contrasts with some other current evidence.

\section{Leptin and immune function}

Leptin is a 167 a polypeptide mainly secreted by the adipose tissue, which act as an endocrine signal in different tissues (39). Leptin receptors, which are widely distributed in the Central Nervous System, are involved in the control of food intake and energy expenditure (40). However, leptin may play other physiological functions, mediated by at least six different receptors isoforms in haematopoiesis, gastrointestinal activity, placenta transport, etc. $(39,40)$.

In this context, leptin seems to participate in a number of immune-related responses such as proinflamatory responses (41), proliferation and development of myeloid cells (42) and other blood-borne cells $(43,44)$, production of lymphokines by T-lymphocytes (45), recovery of depressed immunocompetence induced by fasting (46), and a protective role against TNF- $\alpha$ in systemic inflammatory responses (47). Furthermore, it has been demonstrated that leptin can stimulate the activity of macrophage and neutrophyl colony-forming cells, thus improving the immune response (43). Also, leptin deficiency produces disturbances in lymphoid tissue development (42).

Moreover, leptin appears to have specific effects on helper T-lymphocytes function, through the regulation of the proliferation of cells involved in both innate and acquired immune responses. Thus, leptin increases the production of proinflammatory lymphokines such as IL-2 and interferon $\gamma$, while it inhibits the secretion of IL-4 from the lymphoid cells (45). The interferon $\gamma$ is involved in the stimulation of the phagocytic response from macrophages, while IL-2 promotes the proliferation and differentiation of CD8+ T cells. Some of these effects appear to be mediated by leptin receptors, since the occurrence of the leptin receptor in these blood-borne cells, has been demonstrated by a RT-PCR approach (48). Likewise, the addition of leptin to isolated CD4+ T cells from ob/ob mice, which scarcely produce interferon and IL-4, induced an increase in interferon levels, accompanied by a dose-dependent inhibition of IL-4. Furthermore, it seems that T cells from $o b / o b$ mice are more sensitive to leptin than T-cells from lean mice, while in vitro assays have shown that the expression of some integrins (VLA-2, CD49b) and their ligands (ICAM-1, CD54) in CD4+ cells are induced by leptin, although no effects were found for other adhesion molecules such as CD49a,c,d, CD50 and CD62L (45). Interactions of leptin, which belongs structurally to the long-chain helical cytokine family of IL-2, have been found with IL-6 (49) and other cytokines in situation of infection or anorexia $(50,51)$, while IL-1 appears to increase serum leptin levels in humans (52).

Furthermore, restricted-energy diets reduce plasma leptin levels, while hyperleptinaemia is commonly found in obese individuals, which suggests that this hormone may play a role as a peripheral signal in order to maintain fuel supply for essential functions $(39,40)$. Thus, in starved mice the immunocompetence is reduced as well as the delayed cutaneous hypersensitivity response (53). The administration of leptin to fasted mice reversed the immunosuppressive effects of acute starvation (45). Thus, it has been postu- 
Figure 4 Leptin involvement in immunoregulation as affected by overfeeding and fasting.

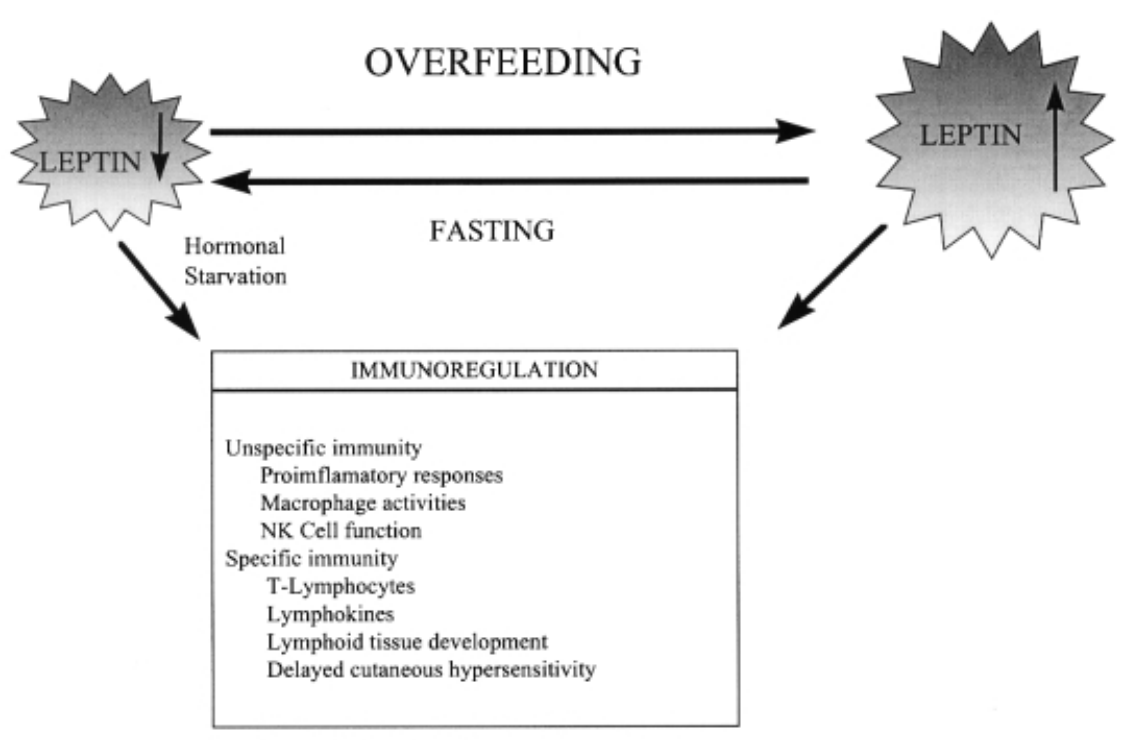

lated that malnutrition may lead to a higher rate of infection and that leptin may promote the immunocompetence recovery (46), leptin being the link between the nutritional status and the immune function (Fig. 4).

Moreover, leptin appears to have a specific effect on $\mathrm{T}$ lymphocyte responses by differentially regulating the proliferation of naive and memory $\mathrm{T}$ cells (45). Specifically, leptin increased Th1 and suppressed Th2 cytokine production (53). These findings further support a role for leptin in linking nutritional status to cognate cellular immune function and provide some light to account for the immune dysfunction in starvation (Fig. 4). According to the previous views, leptin might represent an important target for immune interactions in a variety of pathophysiological conditions (53).

An important and novel function for leptin is the upregulation of inflammatory immune responses, which may provide a common pathogenetic mechanism that contributes to several of the major complications of obesity (41). Furthermore, it has been reported that leptin expression is under partial regulatory control of TNF- $\alpha$ in peritonitis, but anorexia appears not to be related to an increased leptin production (54).

\section{Immune function in obese animal models}

Several studies in genetic animal models suggest that obesity and being overweight are associated with immunocompetence alterations (27,28). Indeed, obese leptindeficient $o b / o b$ mice display low body temperature, hyperphagia, infertility and evidence of immune defects with lymphoid organ atrophy, mainly affecting thymic size and cellularity $(55,56)$. Thus, ob/ob mice, which are unable to synthesize leptin, show some immune disturbances such as a reduced thymus proportion, lower lymphocyte and NK cell numbers as well as decreased cytotoxic activity. Situations of hyperlipidaemia and hyperglycaemia are commonly found in those animals as well as changes in insulin, glucagon, cortisol and ACTH, which might explain some of the abnormalities observed in the ob/ob mice immune response (58).

Genetically obese strains have a lower phagocyte activity by macrophages and a lower expression of proinflammatory-related cytokines (53). Thus, macrophages obtained either from $o b / o b$ mice or from $d b / d b$ mice (animals lacking leptin receptors) are less active in destroying Candida than those isolated from control lean animals, suggesting a role for leptin in the phagocytic process (41). On the other hand, recombinant leptin intraperitoneally administered to $o b / o b$ mice appears to contribute to the improvement of some immune functions and also to the release of a monocyte stimulating factor (41). The impairment in the phagocytic activity from macrophages of genetically obese animals may be associated with the high levels of TNF- $\alpha$, which are known to alter cytokines production (54).

Consistent with this concept, another detailed study identifies several phenotypic abnormalities in macrophages from ob/ob mice (57), including decreased steady-state levels of uncoupling protein-2 mRNA, increased mitochondrial production of superoxide and hydrogen peroxide, induced constitutive activation of CCAAT enhancer binding protein (C/-EBP)- $\beta$ target genes, and increased cyclooxigenase-2 dependent production of PGE2. Given the importance of macrophages in the general regulation of inflammation and immunity, it has been postulated that these alterations in macrophage function may contribute to obesity-related pathophysiology (57). Leptin 
administration protects mice from starvation, as well as induced lymphoid atrophy and increased thymic cellularity in ob/ob mice (59).

Zucker rats, which are genetically obese animals due to the lack of the leptin receptor, showed lymphopenia (low levels of CD4+ and CD8+) in the thymus and the spleen and in the peripheral blood (27). A lower phagocytosis capacity has also been reported in these animals. The proliferative response of spleen cells to mitogen is decreased, which has been associated to a lower glucose uptake mediated by the GLUT-1 transporter (60). Some of these disturbances have been ameliorated by increasing the physical activity of these obese animals (61). Also UCP knocks out these animals, whereas wild animals, which have not developed an obese genotype, appear to be more resistant to infections (62).

\section{Immune function in obese individuals}

Scientific literature contain only a few studies comparing the immune response between lean and obese individuals. Additionally, most experimental trials include only a limited number of subjects and immunological determinations.

Chandra and co-workers (63) have found that $38 \%$ of obese children and adolescents showed a variable impairment of cell-mediated immune responses such as delayed cutaneous hypersensitivity, abnormal lymphoproliferative responses to mitogens and a reduction in intracellular bacterial killing capacity by polymorphonuclear leucocytes. This latter finding was also reported in adults suffering from morbid obesity as compared with non-obese controls (64). Additionally, obesity seems to reduce lymphocyte immune functions and NK cell activity in persons older than 60 years. Therefore ageing is considered as an additional risk factor for obese humans concerning immunocompetence (65). Thus, in elderly women a negative correlation between body fat content and NK cell activity was reported (66), although the mechanisms involved remain still unclear.

Another experimental trial concerning the influence of obesity on immune response in an adult population (67) indicates that obesity is related to elevated leucocyte and lymphocyte subsets counts (unless for NK and cytotoxic/ suppressor T-cells), lower $\mathrm{T}$ and $\mathrm{B}$-cell mitogen-induced lymphocyte proliferation (Fig. 5), which were accompanied by higher monocyte and granulocyte phagocytosis as well as by oxidative burst activity, but normal function of NK cells. The authors of this study suggest that serum cholesterol, triglycerides and glucose levels may be related to impairments in several aspects of immunity, although body mass index (BMI) emerged as the most important correlate factor. In this context, a positive correlation between BMI and total leucocyte was obtained.
Some data from other researchers indicate that the moderate immune stimulation observed in obese individuals may play a role in the development of insulin resistance, where an influence of TNF- $\alpha$ seems to be probable (68) as well as of melanocortin peptides (69). In this context, Type 2 (non-insulin-dependent) diabetes mellitus is associated with an increase of the main cytokine mediator of the acute-phase response, IL-6. Through the action of cytokines on the adipose tissue and elsewhere, this process could be a major contributor to the biochemical and clinical features of the metabolic syndrome and central obesity (70).

A further study carried out by Nieman and co-workers (71) in obese and non-obese women revealed that body fat mass is positively correlated with total leucocyte, neutrophyl, monocyte and lymphocyte counts. However, they were unable to establish any impairment of some immune functions in the obese subjects, becasue T-cell function (PHA and Con A-stimulated lymphocyte proliferation) was comparable between obese and non-obese women, while $\mathrm{B}$ function (PWM-stimulated lymphocyte proliferation) was about $50 \%$ higher in the obese group. Furthermore, monocyte and granulocyte phagocytosis was not influenced by obesity, while basal and activated monocyte and basal granulocyte oxidative bursts were higher in the obese subjects. The data of the obese patients (71), after following a weight loss period, were consistent with the viewpoint that a moderate energy restriction (1200-1390 kcald ${ }^{-1}$ for 12 weeks) is associated with decreases in mitogenstimulated proliferation responses (Fig. 6) and significant decreases in monocyte oxidative bursts as well as of NK cells counts, but not of $\mathrm{T}$ and $\mathrm{B}$ cells counts, which were mainly attributed to the energy drain rather than to reduced micronutrient intake. Contrary to this, other previous studies claim that underlying immune impairments in responsiveness of lymphocytes found in obese people are reversible with adequate weight reduction (72).

Kelley and co-workers (73) have found that a lower number of NK cells and immunoglobulins occurred in overweight women following an energy restricted diet ( $50 \%$ reduction) for 84 days, which was accompanied by $7-9 \mathrm{~kg}$ weight loss. Likewise, Scanga and co-workers (74) pointed out that obese women consuming a restricted diet $\left(950 \mathrm{kcal} \mathrm{d}^{-1}\right)$ combined with a supervized programme of light to moderate intensity aerobic activity and resistance training offsets the apparent decrement in NK cell cytotoxicity as well as other distortions associated to weight loss, such as reductions in CD2+ cells expressing IL-2R $\alpha$. These results are in agreement with data of Pomeroy and co-workers (75), who reported that levels of complement $\mathrm{C}_{3}$ and the alternative haemolytic activity (AP50) are determined, in part, by factors influencing weight changes. Furthermore, surgically induced weight reduction produced a significant decrease in IL-3 and TNF- $\alpha$, which could be 

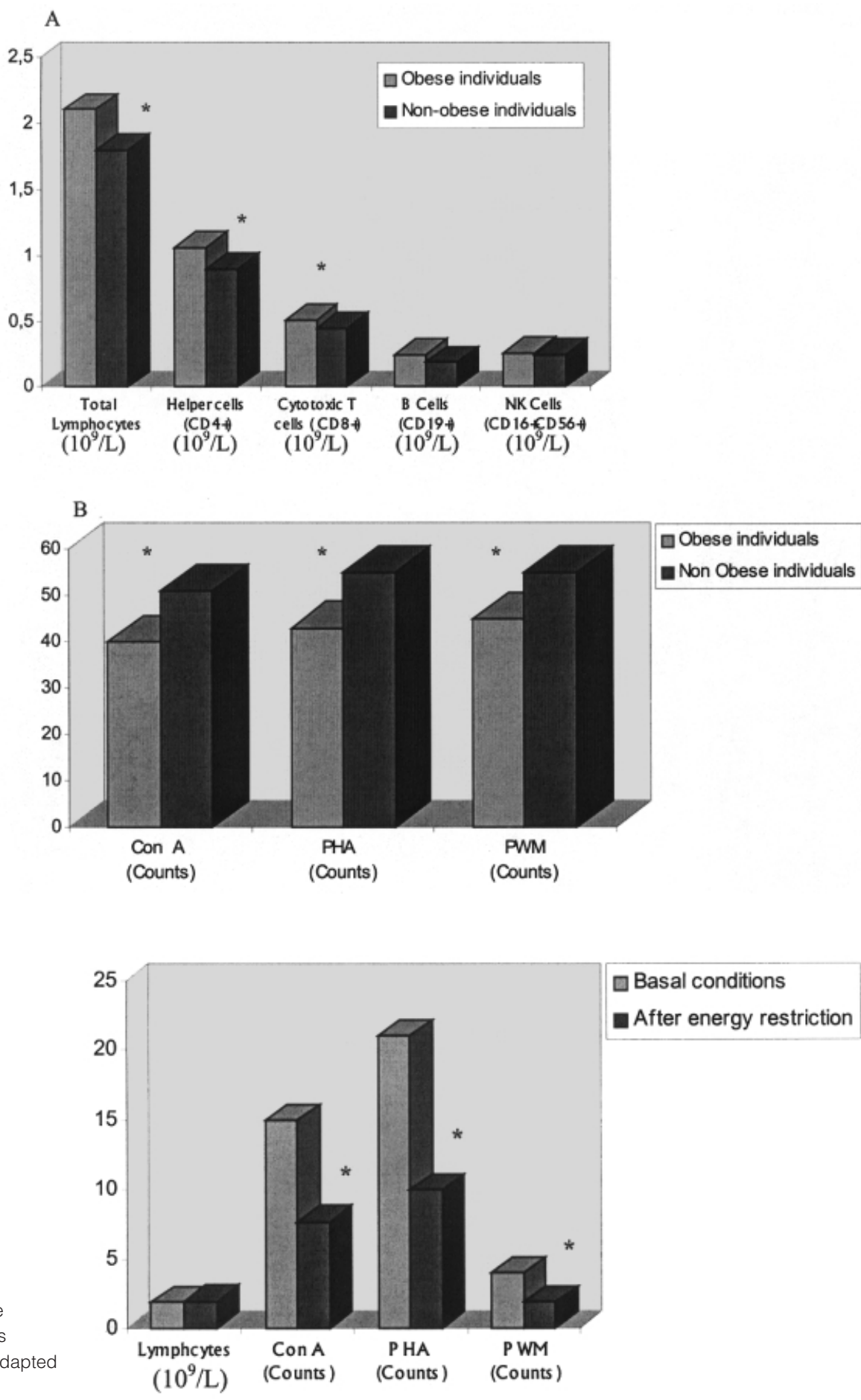
obese and nonobese subjects (Adapted from Nieman et al. 1999(67)). ${ }^{*} P<0.05$.
Figure 5 Lymphocyte counts (A) and proliferative responses to mitogens (B) in

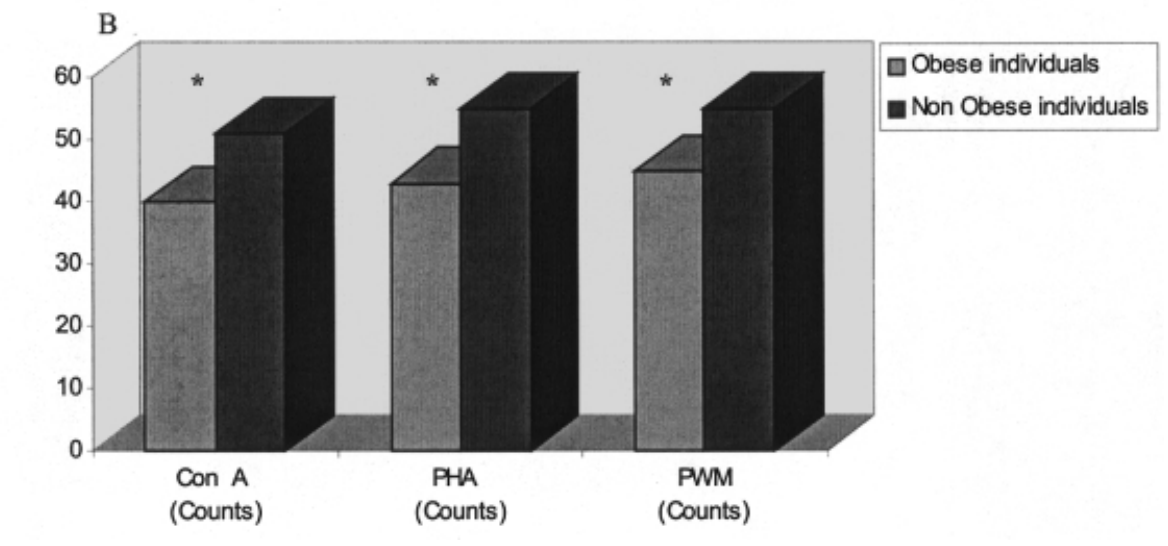

Figure 6 Lymphocyte count and proliferative responses to mitogen in obese individuals as affected by a moderate energy restriction (Adapted from Nieman et al. 1996(71)). ${ }^{\star} P<0.05$. responsible for some alterations in the immune function (76).

The safety of weight loss on the immune system was assessed by a programme consisting of a 7-24-week very low calorie dieat (VLCD) period, in which the numbers of circulating leucocytes, neutrophils, basophils, monocytes, CD3+, CD4+, CD8+, and NK cells did not change signifi- cantly, although a decrease in the Ig $\mathrm{M}$ serum concentrations during the programme was noted (77). These authors suggest that a VLCD programme appears to be suitable for preoperative weight reduction in morbid obesity and seems not to compromise the immune system.

Remarkably, acute nutritional deprivation and shortterm fast periods occur frequently in individuals suffering 


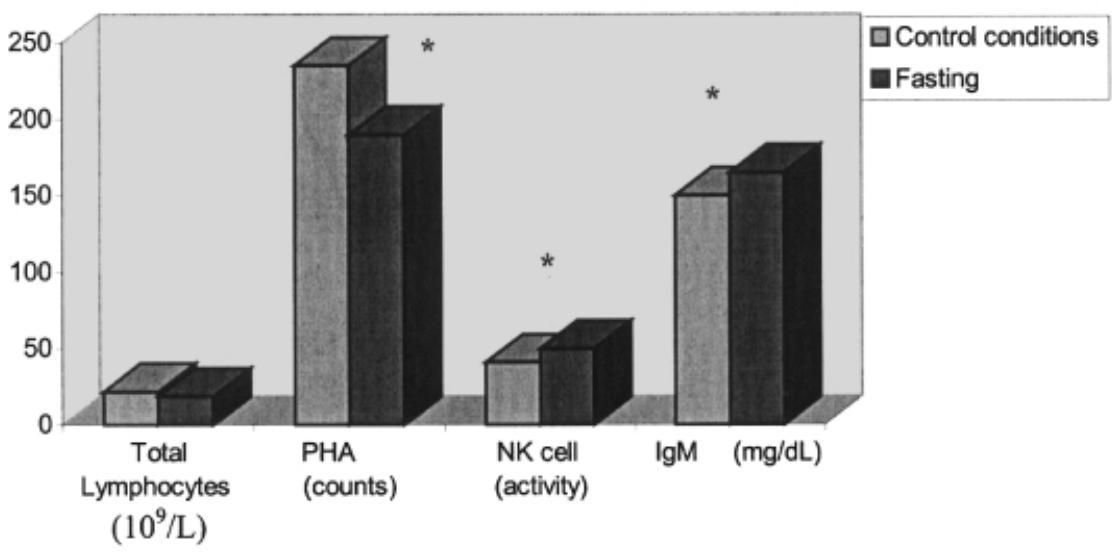

Figure 7 Fasting-induced immune effects in obese subjects (Adapted from Wing et al. 1983(73)). ${ }^{*} P<0.05$ from obesity, which affects the immunocompetence (78). Blood monocyte bactericidal activity and natural killer cell cytolytic activity were enhanced by fasting. Thus, monocyte killing capacity increased in 12 out of 14 subjects and natural killer cell activity increased an average of $24 \%$ in 13 obese subjects tested. Starvation also enhanced parameters of humoral immunity as evidenced by increases in serum concentrations of $\operatorname{IgG}, \operatorname{Ig} \mathrm{A}$ and $\operatorname{IgM}$. By contrast, lymphocyte blastogenic responses to the mitogen PHA were modestly decreased, while peripheral blood leucocyte counts, including neutrophils, $\mathrm{T}$ cells and $\mathrm{B}$ cells, did not decrease significantly. The results indicate that fasting has differential influences on immune function rather than a uniformly deleterious effect (Fig. 7). Of potential importance, this nutritional alteration appears to actually enhance certain effector functions of the host defence system in the obese patient.

\section{Conclusions and applications}

Summing up, the immunological mechanisms involved in the collaborative defence of the organism are challenged by under-nutrition and overeating. Thus, obesity as well as food allergies $(80,81)$ influence unspecific immune functions and specific immunity responses mediated by humoral and cell-mediated mechanisms. Several lines of evidence have supported a link between adipose tissue and immunocompetent cells. The interaction is illustrated in obesity, where excess adiposity and impaired immune function have been described in both humans and genetically obese rodents. In general terms, clinical and epidemiological data support the evidence that the incidence and severity of specific types of infectious illnesses are higher in obese persons as compared to lean individuals, as well as poor antibody responses to vaccinations in overweight subjects. The adipocyte-derived hormone leptin may act as a link between the nutritional status and $\mathrm{T}$ cell function. Moreover, there is evidence that hyperleptinaemia induced by cytokines is an integral part of the acute phase response and necessary for comprehensive immunocompetence. It remains to be seen whether or not leptin will be a useful molecule in the treatment of immunodepressed individuals. The involvement of CNS and the endocrine system, as well as their interrelationships with immune system alterations and dietary behaviour, require further investigations (82). In this context, more research is also needed to clarify the clinical implications of the alterations induced by obesity in immunity and by various interventions such as weight loss (74), exercise and (79) nutrient supplementation (83).

Future key developments in this area are likely to involve the raising of cytotoxic antibodies to adipocytes or immunoglobulins promoting growth and fat deposition. Leptin immunoneutralization, leptin production by extraadipose tissues through gene transfer or even immunological yielding of anti-idiotypes mimicking leptin or other molecule actions could also be expected to participate in the treatment of obesity and immune disturbances.

\section{Acknowledgements}

This work is supported by Linea Especial (UN-98) and the Government of Navarra (Department of Health; 1/99).

\section{References}

1. McHeyzer-Williams MG. Immune response decision at the single cell level. Immunology 1997; 9: 219-227.

2. Abbas AK, Janeway CA JR. Immunology: improving on nature in the twenty-first century. Cell 2000; 100: 129-138.

3. Jaheway J, Travers $\mathrm{T}$ (eds). Immunobiology: The Immune System in Health and Disease. Garland Publishing Inc.: New York, 1997.

4. Sanmartin S, Chandra RK. Obesity, overnutrition and immune system. Nut Res 2000. (In press.)

5. Scrimshaw NS, SanGiovanni JP. Synergism of nutrition. Infection Immunity. Am J Clin Nutr 1997; 66: 464S-477S. 
6. Chandra RK. Nutrition and immunity: lessons from the past and new insights into the future. Am J Clin Nutr 1990; 1991: 1087-1101.

7. Palop L, Martínez JA. Cross-sectional assessment of nutritional and immune status in renal patiens undergoing continuous ambulatory peritoneal dialysis. Am J Clin Nutr 1997; 66: 498S-504S.

8. Chandra RK. Nutrition and the immune system: an introduction. Am J Clin Nutr 1997; 66: 460S-463S.

9. Cunningham-Rundles S. Nutrient Modulation of the Immune Response. Academic Press: New York, 1993.

10. Martinez JA, Macarulla MT, Marcos R, Larralde J. Nutritional otcome and immunocompetence in mice fed on a raw field beans as the source of protein. Br J Nutr 1992; 68: 493-503.

11. Moussa M, Tkaczuk J, Ragab J, Garcia J, Abbal M, Ohayon E, Ghisolfi J, Thouvenot JP. Relationship between the fatty acid composition of rat lymphocytes and immune functions. $\mathrm{Br} \mathrm{J} \mathrm{Nutr}$ 2000; 83: 327-333.

12. Lukito W, Boyce NW, Chandra RK. Nutrition and immunity. In: Walhquist ML, Vovecky JS, (eds). Medical Practice of Preventive Nutrition. Smith-Gordon Ltd.: London, 1994, pp 27-53.

13. Keith ME, Jeejeebhoy KN. Immunonutrition. Baillieres Clin Endochinol Metab 1997; 11: 709-738.

14. Martínez JA, Frühbeck G. Regulation of energy balance and adiposity: a model with new approaches. J Physiol Biochem 1996; 52: 255-258.

15. Friedman JM. Obesity in the new millenium. Nature 2000; 404: 632-635.

16. Bent RT. Indices of height and weight as measures of obesity. Br J Prev Soc Med 1970; 24: 64.

17. World Health Organization. Obesity: preventing and managing the global epidemic. WHO: Geneva, 1998.

18. Weinsier RL, Hunter GR, Heini AF, Goran MI, Sell SM. The etiology of obesity: relative contribution of metabolic factors, diet, and physical activity. Am J Med 1998; 105: 145-150.

19. Martinez J. Obesity in young Europeans: genetic and environmental influences. Eur J Clin Nutr 2000; 54: S56-S60.

20. Astrup A, Lundsgrand C, Stock MJ. Is obesity contagious? Int J Obes 1998; 22: 376-377.

21. Task force for preventing and treatment of obesity. Overweight, Obesity, and Health Risk. Arch Intern Med 2000; 160: 898-904.

22. Bovill EG, Bild DE, Heiss G, Kuller LH, Lee MH, Rock R, Ealh PW. White blood cell counts in person 65 years or more from the Cardiovascular Health study: correlations with baseline clinical and demographic characteristics. Am J Epidemiol 1996; 143: 1107-1115.

23. Sweettman PM, Thomas HF, Yarnell JWG, Baker IA, Elwood PC. Total and differential leukocyte counts as predictors of ischemic heart disease: the Caerphilly and Speedwell studies. Am J Epidemiol 1997; 145: 416-421.

24. Khan LK, Bowman BA. Obesity: a major global public health problem. Annu Rev Nutr 1999; 19: 13-17.

25. Pi-Sunyer FX, Laferrere B, Aronne LJ, Bray GA. Obesity-A modern-day epidemic. J Clin Endocrin 1999; 84: 3-5.

26. Weber DJ, Rutala WA, Samsa GP, Bradshaw SE, Lemon SM. Impaired immunogenicity of hepatitis B vaccine in obese persons [letter]. N Engl J Med 1986; 314: 1393.

27. Tanaka Si Isoda F, Yamakawa T, Ishihara M, Sekihara H. T lymphopenia in genetically obese rats. Clin Immunol Immunopathol 1998; 86: 219-225.

28. Chandra RK, Au B. Spleen hemolytic plaque forming cell response and generation of cytotoxic cells in genetically obese mice (ob/ob). Int Arch Allergy Appl Immunol 1980; 62: 141147.
29. Gottschlich MM, Mayes T, Khoury JC, Warden GD. Significance on nutritional, immunologic, hormonal, and clinical outcome parameters in burns. J Am Diet Assoc 1993; 93: 1261-1268.

30. Marcos A, Varela P, Toro O, Nova E, López-Vidriero I, Morandé G. Evaluation of nutritional status by immunologic assessment in bulimia nervosa: influence of body mass index and vomiting episodes. Am J Clin Nutr 1997; 66: 491S-497S.

31. Marcos A, Varela P, Toro O, Nova E, López-Vidriero I, Morandé G. Interactions betweeen nutrition and immunity in anorexia nervosa: 1-yr follow-up study. Am J Clin Nutr 1997; 66: 485S-491S.

32. Varela P, Marcos A, Santacruz I, Ripoll S, Requejo A. Human immunodeficiency virus infection and nutritional status in female drug addicts undergoing detoxification: anthropometric and immunological assessesment. Am J Clin Nutr 1997; 66: 504S509S.

33. Gregoire FM, Smas CM, Sue HS. Understanding adipocyte differentiation. Physiol Rev 1998; 18: 783-809.

34. Cousin B, Muñoz O, Andre M, Fontanilles AM, Dani C, Cousin JK, Laharrague P, Casteilla K, Penicaud L. A role for preadipocytes as macrophage-like cells. FASEB J 1999; 14: 305-312.

35. Nishhira J. Novel pathophysiological aspects of macrophage migration inhibitory factor. Int J Mol Med 1998; 2: 17-28.

36. Jackson IJ. The mahogany mouse mutation: further links between pigmentation, obesity and the immune system. Trends Genet 1999; 15: 429-431.

37. Auwerx J. PPAR $\gamma:$ a versatile metabolic regulator. Int J Obesity 2000; 24: S4.

38. Norgan NG. The beneficial effects of body fat and adipose tissue in humans. Int J Obes 1997; 21: 738-746.

39. Marti A, Berraondo B, Martínez JA. Leptin: Physiological actions. J Physiol Biochem 1999; 55: 43-50.

40. Trayhurn P, Hoggard N, Mercer JG, Rayner DV. Leptin: fundamental aspects. Int J Obes Relat Metab Disord 1999; 23: S22-S28.

41. Loffreda S, Yang SQ, Lin HZ, Karp CL, Brengman ML, Wang DJ, Klein AS, Bulkley GB, Bao C, Noble PW, Lane MD, Diehl AM. Leptin regulates proinflammatory immune responses. Faseb $J$ 1998; 12: 57-65.

42. Mikhail AA, Beck EX, Shafer A, Barut B, Gbur JS, Zupancic TJ, Schweitzer AC, Cioffi JA, Lacaud G, Ouyang B, Keller G, Snodgrass HR. Leptin stimulates fetal and adult erythroid and myeloid development. Blood 1997; 89: 1507-1512.

43. Gainsford T, Willson TA, Metcalf D, Handman E, Ng A, Nicola NA, Alexander WS. Hilton DJ. Leptin can induce proliferation, differentiation, and functional activation of hematopietic cells. Proc Natl Acad Sci USA 1996; 93: 14564-14568.

44. Santos-Alvarez J, Goberna R, Sanchez-Margalet V. Human leptin stimulates proliferation and activation of human circulating monocytes. Cell Immunol 1999; 194: 6-12.

45. Lord GM, Matarese G, Howard JK, Baker RJ, Bloom SR, Lechler RI. Leptin modulates the T-cell immune response and reverses starvation-induced immunosupression. Nature 1998; 394: 897-901.

46. Flier JS. Lowered leptin slims immune response. Nature Med 1998; 4: 1124-1125.

47. Takahashi N, Waelput W, Guisez Y. Leptin is an endogenous protective protein against the toxicity exerted by tumor necrosis factor. $J$ Exp Med 1999; 189: 207-212.

48. Friedman JM. Leptin, leptin receptors and the pathogenesis of obesity. In: Guy-Grand B, Ailhaud G (eds). Progress in Obesity Research: 8. John Libbey and Company Ltd.: London, 1999, pp 307-326. 
49. Torpy DJ, Bornstein SR, Chrousos GP. Leptin and interleukin6 in sepsis. Horm Metab Res 1998; 30: 726-730.

50. Grunfeld C, Zhao C, Fuller J, Pollack A, MoSeries A, Friedman J, Feingold KR. Endotoxin and cytokines induce expression of leptin, the $o b$ gene product, in hamsters. A role for leptin in the anorexia or infection. J Clin Inves 1996; 97: 2152-2159.

51. Sarraf P, Frederch RC, Turner EM, Ma G, Jaskowiak NT, Rivet DJ, Filier JS, Lowell BB, Fraker DL, Alexander HR. Multiple cytokines and acute inflammation raise mouse leptin levels: potential role in inflammatory anorexia. J Exp Med 1997; 185: 171-178.

52. Janik JE, Curti BD, Considine RV, Rager HC, Powers GC, Alvord WG, Smith JW, Gause BL, Kipp WC. Interleukin-1 increases serum leptin levels in humans. J Clin Endocrinol Metab 1997; 82: 3084-3090.

53. Matarese G. Leptin and the immune system: how nutritional status influences the immune response. Eur Cytokine Netw 2000; 11: 7-14.

54. Moshyedi AK, Josephs MD, Abdalla EK, Mackay SL, Edwards CK, Copeland EM, Moldawe LL. Increased leptin expression in mice with bacterial peritonitis is partially regulated by TNF- $\alpha$. Infect-Immun 1998; 66: 1800-1802.

55. Chandra RK. Cell-mediated immunity in genetically obese (C57BL/6J ob/ob) mice. Am J Clin Nutr 1980; 33: 13-29.

56. Mandel MA, Mahmoud AA. Impairment of cell-mediated immunity in mutation diabetic mice $(d b / d b)$. J Immunol 1978; 120: $1375-1380$

57. Lee FY, Li Y, Yang EK, Yang SQ, Lin HZ, Trush MA, Dannenberg AJ, Diehl AM. Phenotypic abnormalities in macrophages from leptin-deficient obese mice. Am J Physiol 1999; 276: C386-C394.

58. Ahima RS, Prabakaran D, Mantzoros C, Qu D, Lowell B, Marotos-Flier E, Flier JS. Role of leptin in the neuroendocrine response to fasting. Nature 1996; 382: 250-252.

59. Howard JK, Lord GM, Matarese G, Vendetti S, Ghatei MA, Ritter MA, Lechler RI, Bloom SR. Leptin protects mice from starvation-induced lymphoid atrophy and increases thymic cellularity in ob/ob mice. J Clin Invest 1999; 104: 1051-1057.

60. Moriguchi S, Kato M, Sakai K, Yamamoto S, Shimizu E. Decreased mitogen response of splenic lymphocytes in obese Zucker rats is associated with the decreased expression of glucose transport 1 (GLUT-1). Am J Clin Nutr 1998; 67: 1124-1129.

61. Moriguchi S, Kato M, Sakai K, Yamamoto S, Shimizu E. Exercise training restores decreased cellular immune functions in obese Zucker rats. J Appl Physiol 1998; 84: 311-317.

62. Ricquier D, The UCP. family. Int J Obes 2000; 24: S10.

63. Chandra RK, Kutty KM. Immunocompetence in obesity. Acta Paediatr Scand 1980; 69: 25-30.

64. Palmbland J, Hallberg D, Engstedt L. Polymorphonuclear (PMN) function after small intestinal shunt operation for morbid obesity. Br J Haematol 1980; 44: 101-108.

65. Moriguchi S, Oonishi K, Kato M, Kishino Y. Obesity is a risk factor for deteriorating cellular immune functions with aging. Nutr Res 1995; 15: 151-160.

66. Nieman DC, Henson DA, Gusewitch G, Warren BJ, Dotson RC, Butterworth DE, Nehlsen-Cannarella SL. Physical activity and immune function in elderly women. Med Sci Sports Exerc 1993; 25: 823-831.
67. Nieman DC, Henson DA, Nehlsen-Cannarella SL, Ekkens M, Utter AC, Butterworth DE, Fagoaga OR. Influence of obesity on immune function. J Am Diet Assoc 1999; 99: 294-299.

68. Ledochowski M, Murr C, Widner b Fuchs D. Association between insulin resistance, body mass and neopterin concentrations. Clin Chim Acta 1999; 282: 115-123.

69. Mountjoy KG, Wong J. Obesity, diabetes and functions for proopiomelanocortin-derived peptides. Mol Cell Endocrinol 1997; 128: 171-177.

70. Pickup JC, Crook MA. Is type II diabetes mellitus a disease of the innate immune system? Diabetología 1998; 41: 12411248.

71. Nieman DC, Nehlsen-Cannarella SL, Henson DA, Butterworth DE, Fagoaga OR, Warren BJ, Rainwater MK. Immune responses to obesity and moderate weight loss. Int J Obes 1996; 20: 353-360.

72. Tanaka S, Inoue S, Isoda F, Waseda M, Ishihara M, Yamakawa T, Suglyama A, Takamura Y, Okuda K. Impaired immunity in obesity: suppresed, but reversible lymphocyte responsiveness. Int J Obes 1993; 17: 631-636.

73. Kelley DS, Daudu PA, Branch LB, Johnson HL, Taylor PC, Mackey B. Energy restriction decreases number of circulating natural killer cells and serum levels of immunoglobulins in overweight women. Eur J Clin Nutr 1994; 48: 9-18.

74. Scanga CB, Verde Tj Paolone AM, Andersen RE, Wadden TA. Effects of weight loss and exercise training on natural killer activity in obese women. Med Sci Sports Exerc 1998; 30: 1666-1671.

75. Pomeroy C, Mitchell J, Eckert E, Raymond N, Crosby R, Dalmasso AP. Effect of body weight and caloric restriction on serum complement proteins, including factor $\mathrm{d} /$ adipsin: studies in anorexia nervosa and obesity. Clin Exp Immunol 1997; 108: 507-515.

76. Kyzer S, Binyamini J, Chaimaff C, Fishman P. The effect of surgically induced weight reduction on the serum levels of cytokines: IL-3 and TNF- $\alpha$. Obesity Surg 1999; 9: 229-234.

77. Pekkarinen T, Mustajoki P. Use of very low-calorie diet in preoperative weight loss: efficacy and safety. Obes Res 1997; 5: 595-602.

78. Wing EJ, Stanko RT, Winkelstein A, Adibi SA. FastingEnhanced Immune effector mechanisms in obese subjects. Am J Med 1983; 75: 91-96.

79. Nieman DC, Nehlsen-Cannarella SL, Henson DA, Koch AJ, Butterworth DE, Fagoaga OR, Utter A. Immune response to exercise training and/or energy restricition in obese women. Med Sci Sports Exerc 1998; 30: 679-686.

80. Chandra RK. Nutrition and immunology: from the clinic to cellular biology and back again. Proc Nutr Soc 1999; 58: 681-683.

81. O'Hollaren MT. Update in allergy and immunology. Ann Intern Med 2000; 132: 219-226.

82. Marcos A, Montero A, Lopez-Varela S, Morandé G. Eating disorders (obesity, anorexia and bulimia), immunity and infection. In: Tontisirin K, Susking R (eds). Nutrition, Immunity and Infection Disease in Infants and Children. 45th Nestlé Nutrition Workshop: Bangkok, 2000, pp 55-60.

83. Roberfroid MB. Concepts in functional foods. J Nutr 1999; 129: 1398S-1401S. 